\section{A KÖTELEZŐ GÉPJÁRMÜ-FELELŐSSÉGBIZTOSÍTÁS SZEMÉLYI SÉRÜLÉSES KÁRAINAK VIZSGÁLATA}

Hollósnédr. Marosi Judit (MNB vezetỏ aktuárius), hollosnej@mnb.hu

\section{ÖSSZEFOGLALÓ}

Az MNB által létrehozott és működtetett, a hazai kötelező gépjármű-felelősségbiztosítás (kgfb) részletes szerződés- és káradatait tartalmazó Központi Kgfb Tételes Adatbázis (röviden KKTA) adataiból készült az elemzés. A vizsgálat célja annak megállapítása, hogy a károkozó jármüvek és üzembentartóik főbb adatai, továbbá a káresemény helyszíne milyen összefüggést mutatnak a személyi sérüléssel járó káresemények gyakoriságával és a keletkezett kár nagyságával. A KKTA rendszer adatai alapján vizsgált személyi sérüléses károk kárfelhasználása jelentősen eltér a hazai és a külföldön keletkezett károk között. Ez az összehasonlítás több mutató alapján is átlagosan másfélszeres kárfelhasználást jelent a külföldön keletkezett károk esetében. Nagy az egyes károkra történő kárfelhasználások terjedelme, minden évben elöfordulnak néhány ezer forintos, ugyanakkor több száz milliós károk is. Az egyes jármütípusok kárgyakorisága jelentős eltérést mutat, és ebből a szempontból a fiatalok is kockázatosabb közösséget alkotnak.

\section{SUMMARY}

The analysis was prepared from the data of the Central Itemized MTPL Database, which was established and operated by the Hungarian National Bank and contains detailed contract and loss data of vehicle accidents settled under Motor Third Party Liability insurance. The aim of this study is to find out how the data, collected on the policyholder of the vehicle, the vehicle type causing injury and the location of the claim event, connected to the frequency of personal injury and the magnitude of the damage caused by the accident. Based on the above data considering claims with personal injuries the amount of damage significantly different between accidents happened abroad and at home. This comparison based on several statistics represents an average of one and a half times the use of claims for claims incurred abroad. The range of the individual amount of damages is very large, with a few thousand forints and hundreds of millions of damages occurring every year. There is a significant difference of the claim frequency among the different vehicle types, and the young people are creating a more risky group in this respect.
Kulcsszavak: kötelező gépjármü-felelősségbiztosítás, személyi sérülés, kárfelhasználás, jármütípus, kárgyakoriság

Keywords: MPTL - Motor Third Party Liability insurance, personal injury, amount of damage, vehicle type, claim frequency

JEL: G22

DOI: $10.18530 / \mathrm{BK} .2021 .1-2.14$

http://dx.doi.org/10.18530/BK.2021.1-2.14

\section{Bevezetés}

Az MNB által létrehozott és működtetett, a hazai kötelező gépjármű-felelősségbiztosítás (kgfb) részletes szerződés- és káradatait tartalmazó Központi Kgfb Tételes Adatbázis (röviden KKTA) adataiból készült az elemzés. Célunk az volt, hogy a kárt okozó járművek és üzembentartóik adatai alapján, minél részletesebben mutassuk be a személyi sérüléses károkat, valamint azok nagyságát.

A KKTA rendszer 2011-től kezdődően tartja nyilván a kgfb-piac teljes szerződésés kárállományát nem beazonosítható, de jól részletezett formában, amely alkalmas a felügyelet számára a piaci folyamatok áttekintésére és - szükség esetén - az azokba történő beavatkozásra is.

Az adatbázis az egyes káreseményeket a biztosítói gyakorlattal összhangban részkár szinten tartja nyilván, annak megfelelöen, hogy milyen jogcímeken történik a károk rendezése. A részkárok a KKTA adatszolgáltatás során az alábbi kategóriákba sorolhatók: járműkár, személyi sérüléses kár, dologi kár és egyéb kategória. Egy-egy káreseményhez több és többféle részkár is tartozhat, így, kiválasztva a személyi sérülések során történt kártérítéseket, érdemes azokat a továbbiakban részkár szinten elemezni. A személyi sérültek kártérítésében a piaci gyakorlat nem egységes, vannak olyan biztosítók, ahol több sérült esetén minden sérült külön részkáron szerepel, ez a gyakoribb eset, de van, ahol nincs ilyen megbontás, és egy részkárhoz több sérült is tartozhat. Erre vonatkozóan az adatbázis nem tartalmaz információt. Ennek ellenére úgy tekintjük, hogy a részkár szinten történő elemzés a baleset során az egyes sérültekre jutó ráfordításokat mutatja. Ugyanakkor káresemény szintjén, nem részkárokra bontva a kárt, összességében tudjuk megmondani, hogy egy adott káreseményben mennyit fordítottak összesen személyi sérülésre. Mindkét megközelítés járható, ebben az összefoglalóban - kihasználva a KKTA rendszerben lévő lehetőséget - részkárok szintjén készültek a számítások. A továbbiakban a részkár és kár szavak ugyanazt jelentik, így az egyszerűség kedvéért a részkárokat kárnak nevezzük, és ha nem részkár szinten történik a számítás, arra a káresemény kifejezést használjuk. 
Az elemzéshez a 2011-2018 közötti időszakban, a teljes kgfb-piacon keletkezett 35648 kárt vizsgáltuk a KKTA adatai alapján. A károk számának évenkénti megoszlása lényegében követi a KSH személyi sérüléses balesetek évenkénti alakulását, bár a KSH adataihoz viszonyítva a 2012-es legkedvezőbb időszaktól kezdődően kismértékű emelkedés tapasztalható. A kgfb keretén belül rendezik a hazai biztosítottak külföldön okozott kárait is, a személyi sérüléses károknak a káresemény helyszíne szerinti megkülönböztetése fontos része az elemzésnek. A KKTA rendszer kezeli a „Káresemény országa” adatot, amelyet, ha a biztosító nem rögzíti ezt a kárnyilvántartó rendszerében, akkor a „Hiányzik” kóddal helyettesíthet.

A személyi sérüléses károknak a káresemény helyszíne szerinti megkülönböztetése fontos része az elemzésnek.

A részletes adatokat az 1. táblázat tartalmazza, a KSH-val történő összehasonlításban a magyarországi személyi sérüléses balesetek és a KKTA-ban szereplő személyi sérüléses károk szerepelnek.

1. táblázat: A személyi sérüléses károk száma évenként és a káresemény helyszíne szerint

\begin{tabular}{|c|c|c|c|c|}
\hline $\begin{array}{c}\text { Kár } \\
\text { keletkezésének éve }\end{array}$ & Magyarország & Külföld & Hiányzik & Összesen \\
\hline 2011 & 3301 & 474 & 184 & 3959 \\
\hline 2012 & 3012 & 577 & 167 & 3756 \\
\hline 2013 & 3290 & 798 & 173 & 4261 \\
\hline 2014 & 3514 & 704 & 257 & 4475 \\
\hline 2015 & 3613 & 793 & 250 & 4656 \\
\hline 2016 & 3830 & 734 & 353 & 4917 \\
\hline 2017 & 4006 & 678 & 329 & 5013 \\
\hline 2018 & 3842 & 549 & 220 & 4611 \\
\hline Összes eset & 28408 & 5307 & 1933 & 35648 \\
\hline
\end{tabular}

Forrás: $M N B$

Az 1. ábra mutatja 2011-től kezdődően a magyarországi személyi sérüléses baleseteket a KSH [4.] adatai alapján, továbbá a KKTA-ban szereplő, Magyarországon és az egyes években összesen keletkezett személyi sérüléses károk számát. A KSH személyi sérüléses balesetek száma minden évben magasabb, mivel szerepelnek itt például a gyalogosok, kerékpárosok, továbbá olyan gépjárművek által okozott balesetek is, amelyek nem érintik a kgfb szerinti felelősséget.

\section{1. ábra: Személyi sérüléses balesetek száma KSH-KKTA}

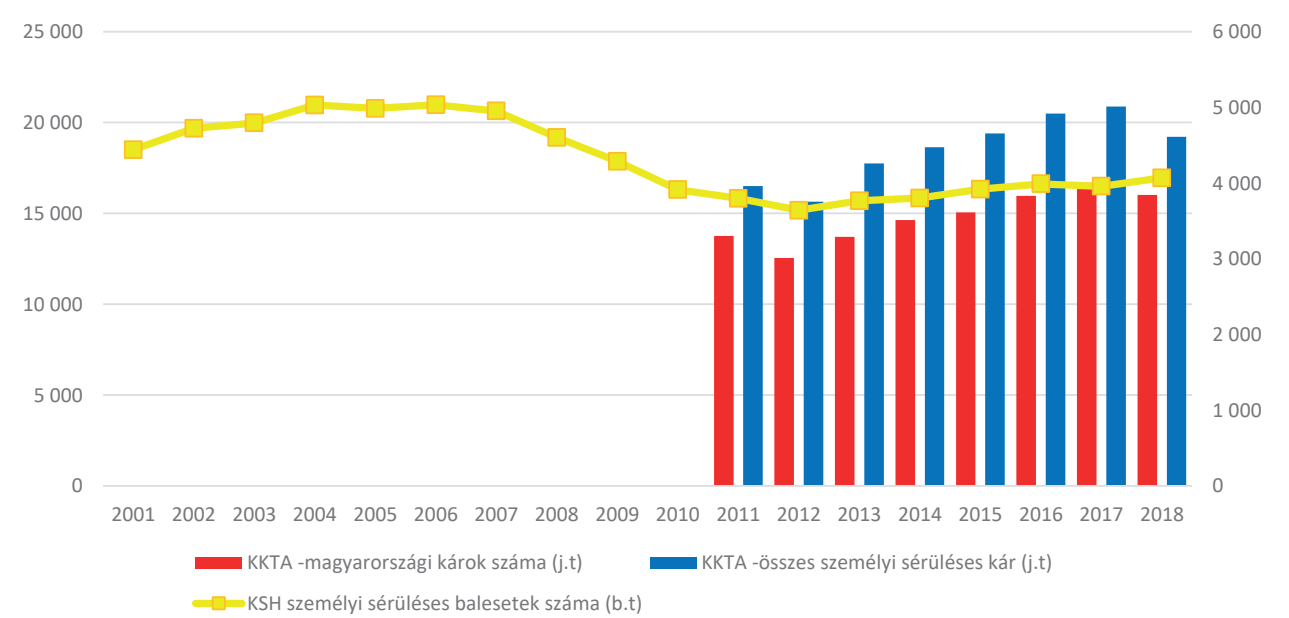

Forrás: KSH, $M N B$

*A 2018-as KKTA adatok néhány biztositónál még nem tartalmazzák a teljes év káradatait.

\section{Célkitüzés}

A vizsgálat fö célja az volt - ahogy a bevezetőben is utaltunk erre -, hogy megállapítsuk, ténylegesen mennyibe kerülnek a személyi sérüléses károk, hogyan viszonyulnak egymáshoz a magyarországi és a külföldön keletkezett károk, továbbá hogyan alakul a személyi sérüléses károk kárgyakorisága a szerződők életkora és a jogszabályban rögzített járműkategóriák között.

A kártérítés mértékére az ún. teljes kárfelhasználás (a továbbiakban kárfelhasználás, kárráfordítás) fogalmat használjuk, és minden esetben forintban adjuk meg. Ez az érték a biztosítók által az egyes károkra megadott összes kárkifizetés, az adott hatálynapra érvényes függőkártartalék, járadékosok esetében még a járadéktartalék és a kifizetett járadékok, együttes összegéből levonva a regressz megtérülés és regressz tartalék értékét, amelyek jogszabályban rögzített feltételek esetén megilletik a biztosítót. A felsorolt adatok a KKTA rendszerben 2020. április 15-i hatálynapon lekérdezett állapotot mutatják. Valamennyi adat bruttó, költségrész nélküli összeggel szerepel, nem véve figyelembe a biztosítók VB politikája miatti esetleges korrekciót. Ezen megközelítés alapján kihagytuk azokat a személyi sérüléses károkat, amelyek kárfelhasználása a várható regressz megtérülés miatt $100 \mathrm{Ft}$ alatti összeg, azaz a biztosítónak nincs kártérítési kötelezettsége. A 2009. évi LXII. törvény a kötelező gépjármű-felelősségbiztosításról 13.\$(1) pontja megadja egy káreseményre vonatkozóan a biztosítók helytállási kötelezettségének felső határát, ami személyi sérüléses károknál 6.070.000 EUR (az árfolyamtól függően 2 milliárd Ft körüli összeg). Ez azt jelenti, hogy 
ha egy káreseményen belül több a sérült személy, és több személyi sérüléses részkár is tartozik a káreseményhez, akkor azok együttes összegére vonatkozik a megadott limit. Sajnálatos módon a személyi sérüléses károk között a limithez közeli káresemények is előfordulnak (pl. veronai buszbaleset)

\section{Kárfelhasználás}

A 8 év adatai alapján láthatjuk, hogy a személyi sérülésre fordított kárösszegek terjedelme nagyon nagy, előfordulnak 5000 Ft vagy annál kisebb összegek, tartalékok, például a helyi vagy távolsági tömegközlekedés járművein történt könnyű sérülések során a károsult nem jelentkezett, esetleg nem is fog jelentkezni kártérítési igénnyel. Ugyanakkor van példa több száz milliós károkra is, 145 esetben a kárösszeg 100 millió Ft feletti. Az évenként előforduló 4-5 ezer személyi sérüléses kár esetében is látható nagy terjedelem miatt az egyes kárévek elemzése helyett a későbbiekben elsősorban a hazai és külföldi/nemzetközi károkat hasonlítjuk össze a rendelkezésre álló 8 év adatai alapján. A kárfelhasználás nagy terjedelme miatt az átlagos kárfelhasználás nem feltétlenül a legjobb adat az összehasonlításhoz, ezért megadjuk az előforduló kárráfordítások átlagai mellett azok Mediánját, ami azt az értéket mutatja meg, amelynél az adatok felében (50\%-ában) ennél kisebb lett a kárfelhasználás. Szintén gyakran alkalmazott mutató a nagy terjedelmű adatok esetében az ún. Nyesett átlag, amely az adatok legkisebb és legnagyobb értékeiből az alsó és felső $5 \%$ levágásával számítja a megmaradó adatok átlagát.

A 2. táblázat mutatja évenként a felsorolt statisztikai mutatószámokat.

2. táblázat: A személyi sérüléses károk föbb statisztikai mutatói a vizsgált időszakban

\begin{tabular}{|c|c|c|c|c|c|}
\hline Kár éve & Károk száma & $\begin{array}{c}\text { Átlagos } \\
\text { kárfelhasználás }\end{array}$ & Medián & Nyesett átlag & Maximális érték \\
\hline $\mathbf{2 0 1 1}$ & 3959 & 4022227 & 1000000 & 2038756 & 794790344 \\
\hline $\mathbf{2 0 1 2}$ & 3756 & 4130864 & 1150933 & 2243321 & 435204000 \\
\hline $\mathbf{2 0 1 3}$ & 4261 & 4187794 & 1100000 & 2163903 & 708401334 \\
\hline $\mathbf{2 0 1 4}$ & 4475 & 4182200 & 1200000 & 2148305 & 549545361 \\
\hline $\mathbf{2 0 1 5}$ & 4656 & 4706911 & 1279900 & 2292127 & 1675582195 \\
\hline $\mathbf{2 0 1 6}$ & 4917 & 4704175 & 1250000 & 2475036 & 520149381 \\
\hline $\mathbf{2 0 1 7}$ & 5013 & 4878927 & 1350000 & 2638332 & 743984268 \\
\hline $\mathbf{2 0 1 8}$ & 4611 & 5427699 & 1495000 & 2936983 & 874924251 \\
\hline Összesen & $\mathbf{3 5 6 4 8}$ & $\mathbf{4 5 5 9 3 0 3}$ & $\mathbf{1 2 0 6 9 5 8}$ & $\mathbf{2 3 8 9 0 0 0}$ & $\mathbf{1 6 7 5} \mathbf{3 8 2} \mathbf{1 9 5}$ \\
\hline
\end{tabular}

Forrás: $M N B$
Az adatok alapján 2015-től látunk emelkedést mind az átlagos kárfelhasználásban, mind a Nyesett átlag nagyságában. A Medián értéke végig 1,5 millió Ft alatti, azaz a károk felénél ennél kisebb volt a kárfelhasználás. A Maximum értékek szerint minden évben előfordultak kiemelkedően nagy károk, a 2015-ös 1,676 milliárdos érték az összesített adatok alapján is jelentős összeg.

A 2. táblázatban szereplő Átlagos kárfelhasználás, Medián és Nyesett átlag 2011-től kezdődő kumulált inflációs trendjét - a KSH fogyasztói árindex [5.] hasonló adatával összehasonlítva - mutatja a 2. ábra. A személyi sérüléses károkra fordított kárösszegek nagyban függenek a sérülés súlyosságától, ami nem feltétlenül követi a fogyasztói árindex változását, ahogy az az ábrából is látható. A KKTA-ban nyilvántartott ún. jármükárok esetében, ahol a kárösszeg elsősorban az alkatrészek és a munkadíjak nagyságával van összefüggésben, inkább várható a fogyasztói árindexszel való együttmozgás.

2. ábra: A személyi sérüléses károk főbb statisztikai mutatóinak kumulált inflációs trendje 2011-2018 között

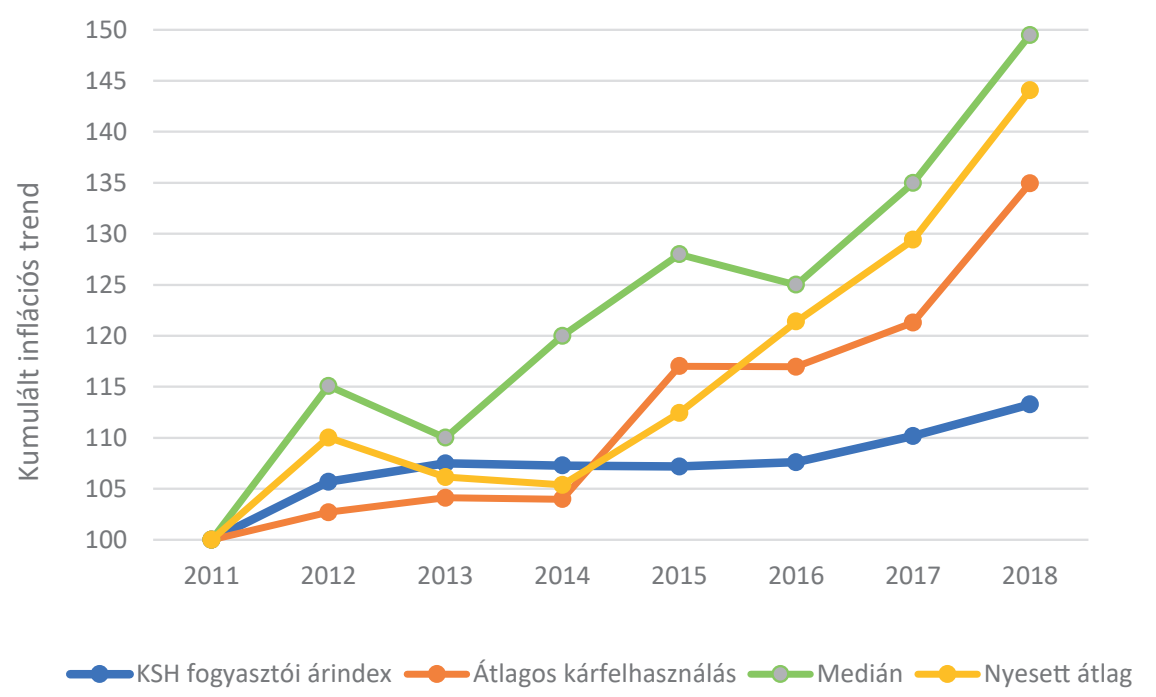

Megjegyzés: $2011=100 \%$

Forrás: KSH, MNB

A Medián értéke nőtt meg legjobban 2011-hez képest, 50\%-kal, miközben a KSH fogyasztói árindexe a 2013-2016 közötti időszak stagnáló 100-as értékei miatt 2018-ra csak 13\%-os növekedést ért el ugyanezen időszakban. A Nyesett átlag 2014-től kezdve mutat 
szigorú monotonitást és jelentős növekedést. Nem szabad azt sem figyelmen kívül hagyni, hogy az évi káresemények száma mindössze 4 ezer körüli, nagy terjedelemmel, ami jelentős volatilitást eredményezhet az egyes évek között.

\section{Hazai és nemzetközi személyi sérüléses károk összehasonlítása}

A károk nagyságát vizsgálva az egyik fontos dolog, hogy másképp történik a magyarországi és az ún. külföldi (nemzetközi) károk rendezése. A hazai gyakorlatban a biztosítók kártérítési kötelezettségüket a társadalombiztosítási szervek (egészség- és nyugdíbbiztosítás) felé egyösszegű megállapodás formájában rendezik, amelyet a MABISZ keretén belül évenként egyenlítenek ki a kgfb-ben érintett biztosítók. Így ezek a költségek nem jelennek meg a KKTA adatszolgáltatásban.

\section{Egyre inkább elötérbe kerülnek itthon is az ún.}

egyösszegủ megváltások.

A külföldön történt károknál viszont megjelenik az ottani kórházi ellátás, ápolás, szállítás stb. költsége, de ha a károsult magyarországi lakos, akkor hazaszállítása után még sor kerülhet az itthoni további gyógykezelésére, ami a MABISZ egyezség része. Összességében emiatt a magyarországi károk olcsóbbak lehetnek. Ugyanakkor a külföldi személyi sérüléses károkhoz a rendelkezésre álló adatok alapján mindössze 4 esetben (3 magyarországi károsult és 1 hiányzó adat) fordul elő járadékszolgáltatás. Ennek tartaléka (felelősségbiztosítási járadéktartalék) elsősorban a hazai károkra történő kárfelhasználást növeli a tartalék jogszabályban rögzített biztonságos mértéke miatt. Egyre inkább előtérbe kerülnek itthon is az ún. egyösszegű megváltások, amikor a járadék folyósítása helyett olyan kártérítési összegben egyeznek meg az ügyféllel, ami egy összegben pótolja a rendszeres járadékfizetést. Külföldi sérültek esetében sem járadékkifizetés, sem járadéktartalék nem szerepel az adatok között, feltehetően egyösszegű kártérítés történik. A kárfelhasználásban megjelenő járadéktartalék (amelyet jogszabályban rögzített prudenciális elvárásoknak megfelelően képeznek a biztosítók) minden esetben magasabb az egyösszegű megváltásra javasolt összegnél (járadék tőkeértéke), emiatt a magyarországi járadékosokra, ha nem járadékszolgáltatásban részesülnének, alacsonyabb lenne a teljes kárfelhasználás. Mindezek alapján célszerủ a hazai és a nemzetközi károk különválasztása. Mivel az egyes években a külföldi károk száma 500-800 közötti volt, így az évenkénti összehasonlítás - pont a kis elemszám és nagy terjedelem miatt - nem ad megbízható eredményt, emiatt a hazai és nemzetközi károkat a 8 év adatai alapján összevonva vizsgáljuk. A 3. táblázat mutatja a külföldi és hazai károk fóbb adatait, kiegészítve még az előforduló kárfelhasználások $25 \%$ és $75 \%$-os percentiliseivel, amelyek azokat az értékeket mutatják, ahol az előforduló kárráfordítások az adatok 25, illetve 75\%-ában ezeknél az értékeknél alacsonyabbak voltak.
3. táblázat: A hazai és külföldi károk statisztikai adatai 2011-2018

\begin{tabular}{|l|c|c|c|c|}
\hline \multicolumn{1}{|c|}{ Föbb adatok } & $\begin{array}{c}\text { Magyarországi } \\
\text { károk }\end{array}$ & Külföldi károk & Külföldi/hazai arány & $\begin{array}{c}\text { Összesen a hiányzó } \\
\text { adatokkal együtt }\end{array}$ \\
\hline Károk száma & 28408 & 5307 & $19 \%$ & 35648 \\
\hline $\begin{array}{l}\text { Átlagos } \\
\text { kárfelhasználás }\end{array}$ & 4128342 & 6228356 & $151 \%$ & 4559303 \\
\hline Medián & 1127940 & 1980162 & $176 \%$ & 1206958 \\
\hline 25\%-os percentilis & 251927 & 665017 & $264 \%$ & 300000 \\
\hline $75 \%$-os percentilis & 3445797 & 4000000 & $116 \%$ & 3574905 \\
\hline „Nyesett átlag" & 2266484 & 2926699 & $129 \%$ & 2389000 \\
\hline Maximális érték & 1675582195 & 794790344 & & 1675582195 \\
\hline
\end{tabular}

Forrás: $M N B$

A nemzetközi károk leggyakoribb helyszínei, ahol az ország neve is ismert az adatszolgáltatásból, Nagy-Britannia, Németország, Ausztria, Olaszország és Románia. (Lásd 4. táblázat) Ezekben az országokban történt a külföldi károk több mint fele, de szerepelnek távoli országok is (pl. Malajzia, Ausztrália, Szenegál, Namíbia) 1-1 káreseménnyel.

4. táblázat: A nemzetközi károk leggyakoribb helyszínei

\begin{tabular}{|l|c|c|}
\hline Ország & Esetszám & Átlagos kárfelhasználás (Ft) \\
\hline Nagy-Britannia & 1346 & 4605209 \\
\hline Németország & 940 & 6355177 \\
\hline Ausztria & 540 & 6057331 \\
\hline Olaszország & 448 & 12425957 \\
\hline Románia & 117 & 7686602 \\
\hline
\end{tabular}

Forrás: $M N B$

A keletkezett károk helyszíne alapján jól érzékelhető a hazai és külföldi károk közötti eltérés, a külföldi károk eloszlása sokkal inkább tolódik a magasabb kárfelhasználások felé. Átlagban a hazai károknak a másfélszerese a külföldön keletkezett károk nagysága, de egy-egy mutató más-más arányt eredményez, pl. a medián már 176\%-a a hazai károk hasonló adatának. A 3. ábrán látható exponenciális eloszlás szerinti illesztésekben pedig a külföldi károkra kapott várható érték 1,8-szorosa a magyarországi becslésnek.

A 3. ábra a magyarországi és a külföldön keletkezett személyi sérüléses károk kárfelhasználásának 1 millió forintos kategóriák szerinti megoszlását mutatja. 
A magyarországi károk közel fele 1 millió forint alatti, ahogy ezt a 3. táblázatban szereplő Medián is mutatja, a külföldi károk nagyobb arányban fordulnak elő az 1 millió Ft feletti kategóriákban.

3. ábra: Személyi sérüléses károk kárnagyság szerinti \%-os megoszlása a kár keletkezésének helye szerint

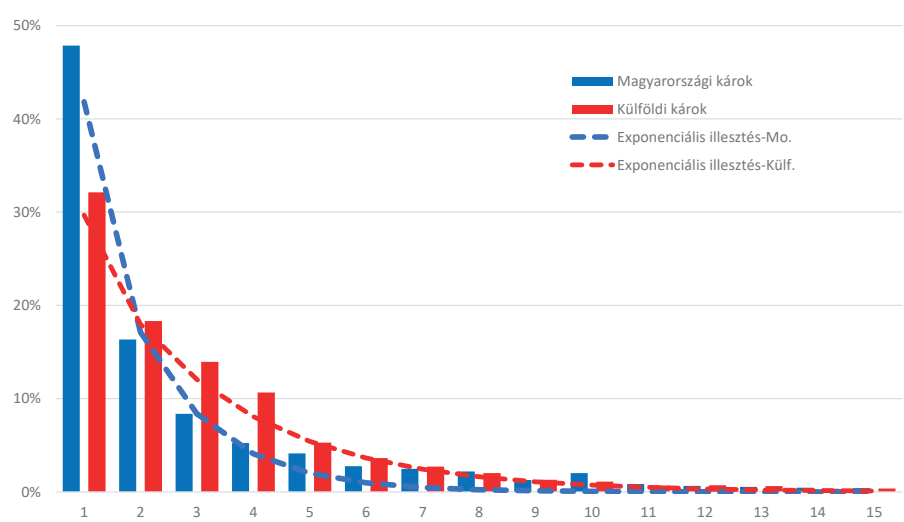

Forrás: $M N B$

Az összehasonlítást tovább részletezhetjük aszerint, hogy a károsult magyarországi vagy külföldi lakos. Erre vonatkozóan is tartalmaz a KKTA rendszer adatot „Sérült személy országa” címen, azonban itt is lehetőségük van a biztosítóknak, hogy a „Hiányzik” kóddal helyettesítsék a rendszerükben a sérült személyére vonatkozóan nem rögzített adatot. A vizsgált adatok között 15320 a „Hiányzik” esetek száma, így csak 19328 eset alapján tudunk összehasonlítást végezni. A hiányzó adatok miatt ez az összehasonlítás csak tájékoztató jellegü, nem jellemzi a teljes kárállományt. Érdekesség ebben a mintában, hogy a legdrágábbak a külföldön megsérült magyar károsultak, ahogy ez az 5. táblázatból látható.

5. táblázat: Magyarországi és külföldi személyi sérüléses károk kárfelhasználása a hazai és külföldi sérült személyekre

\begin{tabular}{|c|r|r|r|r|}
\hline \multirow{2}{*}{ Föbb adatok } & \multicolumn{2}{|c|}{ Magyarországon történt károk } & \multicolumn{2}{c|}{ Külföldön történt károk } \\
\cline { 2 - 5 } & Magyar sérültek & \multicolumn{1}{|c|}{ Külföldi sérültek } & Magyar sérültek & \multicolumn{1}{c|}{ Külföldi sérültek } \\
\hline Esetszám & 15311 & 351 & 1503 & 2155 \\
\hline Átlag & $\mathbf{3 8 4 4 3 5 1}$ & $\mathbf{4 5 7 5 0 8 7}$ & $\mathbf{7 2 2 9 6 6 7}$ & $\mathbf{5 4 2 2 3 1 9}$ \\
\hline Maximum & 549545361 & 110174532 & 794790344 & 685821596 \\
\hline
\end{tabular}

Forrás: $M N B$

\section{A károk keletkezése és bejelentésének üteme hazai és nemzetközi károk esetében}

A biztosítók tartalékolási gyakorlatához fontos adat, hogy a bekövetkezett károk milyen ütemben lesznek ismertek a biztosítók számára, azaz mennyi idő telik el a bekövetkezés és bejelentés között. Ezt az ütemet mutatja be a 6 . táblázat két része, külön a magyarországi, külön a külföldön keletkezett károk esetében.

6. táblázat: A személyi sérüléses károk keletkezése és bejelentésének üteme

Magyarország

\begin{tabular}{|c|c|c|c|c|c|c|c|c|c|}
\hline & \multicolumn{9}{|c|}{ Bejelentés éve } \\
\hline Kárbekövetkezés éve & 2011 & 2012 & 2013 & 2014 & 2015 & 2016 & 2017 & 2018 & 2019 \\
\hline 2011 & $72,3 \%$ & $21,6 \%$ & $3,6 \%$ & $1,7 \%$ & $0,4 \%$ & $0,4 \%$ & $0,1 \%$ & $0,0 \%$ & $0,0 \%$ \\
\hline 2012 & & $70,6 \%$ & $24,8 \%$ & $2,8 \%$ & $1,0 \%$ & $0,4 \%$ & $0,4 \%$ & $0,1 \%$ & $0,0 \%$ \\
\hline 2013 & & & $74,0 \%$ & $22,0 \%$ & $2,6 \%$ & $0,9 \%$ & $0,3 \%$ & $0,2 \%$ & $0,0 \%$ \\
\hline 2014 & & & & $71,8 \%$ & $24,2 \%$ & $2,4 \%$ & $1,1 \%$ & $0,4 \%$ & $0,2 \%$ \\
\hline 2015 & & & & & $74,2 \%$ & $21,4 \%$ & $2,8 \%$ & $1,1 \%$ & $0,4 \%$ \\
\hline 2016 & & & & & & $73,1 \%$ & $23,3 \%$ & $2,5 \%$ & $1,0 \%$ \\
\hline 2017 & & & & & & & $73,2 \%$ & $23,7 \%$ & $3,0 \%$ \\
\hline 2018 & & & & & & & & $77,0 \%$ & $22,2 \%$ \\
\hline
\end{tabular}

Külföldön keletkezett károk

\begin{tabular}{|c|c|c|c|c|c|c|c|c|c|}
\hline \multirow[b]{2}{*}{ Kárbekövetkezés éve } & \multicolumn{9}{|c|}{ Bejelentés éve } \\
\hline & 2011 & 2012 & 2013 & 2014 & 2015 & 2016 & 2017 & 2018 & 2019 \\
\hline 2011 & $50,6 \%$ & $27,4 \%$ & $13,9 \%$ & $5,3 \%$ & $1,5 \%$ & $0,6 \%$ & $0,1 \%$ & $0,0 \%$ & $0,0 \%$ \\
\hline 2012 & & $41,2 \%$ & $34,8 \%$ & $16,1 \%$ & $6,1 \%$ & $1,2 \%$ & $0,4 \%$ & $0,2 \%$ & $0,0 \%$ \\
\hline 2013 & & & $56,1 \%$ & $29,6 \%$ & $9,4 \%$ & $3,6 \%$ & $0,3 \%$ & $0,8 \%$ & $0,1 \%$ \\
\hline 2014 & & & & $63,4 \%$ & $27,1 \%$ & $7,0 \%$ & $1,1 \%$ & $0,3 \%$ & $0,4 \%$ \\
\hline 2015 & & & & & $59,8 \%$ & $31,7 \%$ & $2,8 \%$ & $2,0 \%$ & $0,5 \%$ \\
\hline 2016 & & & & & & $63,6 \%$ & $23,3 \%$ & $6,5 \%$ & $2,2 \%$ \\
\hline 2017 & & & & & & & $68,9 \%$ & $25,7 \%$ & $5,3 \%$ \\
\hline 2018 & & & & & & & & $69,4 \%$ & $30,1 \%$ \\
\hline
\end{tabular}

Forrás: $M N B$

A kétféle adatsor alapján látszik, hogy a hazai károk mintegy 70\%-a még az adott évben ismertté válik, míg a nemzetközi károknál ez az arány 50-60\% körüli. A hazai károk megközelítőleg 98\%-a a káresemény bekövetkezését követő második év végére már bejelentésre kerül, a nemzetközi károk bejelentési üteme ennél lassúbb, és csak a káreseményt követő harmadik év végére érik el ezt a 98\% körüli arányt. 


\section{A személyi sérüléses károk alakulása a károkozó gépjármủ szerint}

A jogszabályban rögzített járműkategóriák szerint vizsgálva a 8 év során keletkezett személyi sérüléses károk arányát, azt mondhatjuk, hogy azok nagy többségben olyanok, mint a jármütípusok állományon belüli megoszlása szerinti arányok. A 7. táblázat azokat a járműkategóriákat mutatja, ahol vagy kifejezetten alacsony, vagy kifejezetten magas a károkozás aránya az állományi részesedéshez képest.

Ennél fontosabb a személyi sérüléses károkat nagyobb arányban okozó jármúkategóriák bemutatása.

Csupán érdekességként érdemes felsorolni a segédmotoros kerékpárt, a pótkocsikat és a lassú járművet, mint személyi sérüléses kárt alig okozókat. Ennél fontosabb a személyi sérüléses károkat nagyobb arányban okozó járműkategóriák bemutatása. Ebből a szempontból első helyen szerepelnek a vontatók, de az autóbuszok között is nagyobb a személyi sérüléses károk aránya. Az autóbuszoknál ez várható, mert többnyire a járműben utazók is sérülnek egy-egy káresemény során. A trolibuszok a szűk utcákban közlekedve okoznak kárt, és a benne utazók a hirtelen fékezés miatt sérülhetnek. Ebbe a csoportba sorolhatók még a közepes kategóriájú tehergépkocsik is.

7. táblázat: Személyi sérüléses károkat az állományi megoszlásuknál kisebb és nagyobb arányban okozó jármükategóriák

\begin{tabular}{|c|c|c|c|}
\hline Járműtípus & Állományon belüli arány & Károkon belüli arány & $\begin{array}{l}\text { Káron belüli arány/ } \\
\text { Állományon belüli arány }\end{array}$ \\
\hline Segédmotoros kerékpár & $6,94 \%$ & $0,31 \%$ & 0,04 \\
\hline Pótkocsi $0,75-10 \mathrm{t}$ & $5,28 \%$ & $0,01 \%$ & 0,00 \\
\hline Lassú jármü & $3,04 \%$ & $0,49 \%$ & 0,16 \\
\hline Pótkocsi 0-0,75 t & $2,31 \%$ & $0,11 \%$ & 0,05 \\
\hline Pótkocsi 10- $\mathrm{t}$ & $1,14 \%$ & $0,20 \%$ & 0,18 \\
\hline Motorkerékpár 13-35 kW & $1,01 \%$ & $0,19 \%$ & 0,19 \\
\hline Motorkerékpár 0-12 kW & $0,68 \%$ & $0,07 \%$ & 0,10 \\
\hline Munkagép & $0,11 \%$ & $0,01 \%$ & 0,09 \\
\hline Vontató & $0,72 \%$ & $8,83 \%$ & 12,26 \\
\hline Autóbusz 80 - féróhely & $0,12 \%$ & $2,62 \%$ & 21,83 \\
\hline Tehergépkocsi 3,5-12 t & $0,59 \%$ & $2,55 \%$ & 4,32 \\
\hline Autóbusz 43-79 férőhely & $0,09 \%$ & $1,30 \%$ & 14,44 \\
\hline Autóbusz határozott idejú & $0,05 \%$ & $0,90 \%$ & 18,00 \\
\hline Trolibusz & $0,01 \%$ & $0,24 \%$ & 24,00 \\
\hline
\end{tabular}

Forrás: $M N B$
Érdemes azt is megvizsgálni, hogy az egyes jármükategóriák károkozás helye szerinti kárgyakoriságai hogyan alakultak. A 8. táblázat alapján a külföldön keletkezett károk aránya 16\% a magyarországi és külföldi károk között. Ehhez viszonyítva vizsgáljuk az egyes járműkategóriák külföldön okozott kárainak arányát. Bizonyos járműkategóriákhoz tartozó járművek egyáltalán nem okoztak külföldön károkat, például trolibusznál ez szóba se jöhet, de a lassú jármű, mezőgazdasági vontató, munkagép és a kis pótkocsik sem okoztak külföldön személyi sérüléses kárt.

8. táblázat: Az egyes jármủkategóriák küllföldön és Magyarországon keletkezett személyi sérüléses kárai 2011-2018 között

\begin{tabular}{|l|c|}
\hline \multicolumn{1}{|c|}{ Jármü típusa } & \multicolumn{1}{|c|}{$\begin{array}{c}\text { Külföldi károk aránya a magyarországi és } \\
\text { külföldi károk együttesén belül }\end{array}$} \\
\hline Vontató & $86,3 \%$ \\
\hline Pótkocsi 10t- & $84,9 \%$ \\
\hline Tehergépkocsi 12- $\mathrm{t}$ & $27,2 \%$ \\
\hline Autóbusz 20-42 férőhely & $26,7 \%$ \\
\hline Tehergépkocsi 3,5-12 $\mathrm{t}$ & $24,1 \%$ \\
\hline Autóbusz 43-79 féróhely & $21,3 \%$ \\
\hline Tehergépkocsi határozott idejü szerződés & $20,0 \%$ \\
\hline Öszzesen arány & $\mathbf{1 6 , 1 \%}$ \\
\hline Motorkerékpár 70- $\mathrm{kW}$ & $15,7 \%$ \\
\hline Személygépkocsi határozott idejú szerződés & $15,2 \%$ \\
\hline Személygépkocsi 101-180 kW & $12,4 \%$ \\
\hline Motorkerékpár 36-70 kW & $11,5 \%$ \\
\hline Személygépkocsi 71-100 $\mathrm{kW}$ & $9,5 \%$ \\
\hline Személygépkocsi 180- $\mathrm{kW}$ & $9,0 \%$ \\
\hline Motorkerékpár 13-35 kW & $8,7 \%$ \\
\hline Tehergépkocsi $0-3,5 \mathrm{t}$ & $8,7 \%$ \\
\hline Határozott P frsz. & $7,7 \%$ \\
\hline Személygépkocsi $51-70 \mathrm{~kW}$ & $6,6 \%$ \\
\hline Autóbusz 10-19 féróhely & $5,0 \%$ \\
\hline
\end{tabular}

Forrás: $M N B$

A táblázatban a külföldi károk arányai nagyság szerint csökkenő sorrendben szerepelnek, és csak azok a jármútípusok láthatóak, amelyeknél a külföldön okozott károk aránya legalább 5\%.

Az első helyen szereplő vontatókról ismert ez az arány a nemzetközi forgalomban való részvételük miatt. Külön ki kell emelni a második helyen álló „Pótkocsi 10- t” kategóriát, 
amely elsősorban a németországi és spanyolországi gyakorlat alapján, a vontatókkal együtt közlekedve, a vontatók és pótkocsik közötti kármegosztása alapján lesz „károkozó”. Ennek jelentős hatása volt a hazai kgfb-biztositás piacán, amikor a biztositók mindenféle kárstatisztikai megalapozottság nélkül kezdték irreálisan magas áraikkal „kiárazni” a nagy pótkocsikat. Az autóbuszok szintén a külföldi szállitások során a sok sérülttel, halálesettel végződő baleseteik miatt kerülnek az első helyekre. A tehergépkocsik is a nemzetközi forgalomban való részvételük miatt szerepelnek magas aránnyal.

\section{Károkozók életkora szerinti károk}

Vizsgáltuk, hogy a személyi sérüléses károk károkozói a felügyeleti adatszolgáltatásban is alkalmazottéletkor kategóriák szerinti megoszlása hogyan viszonyul a szerződőkéletkorcsoportok szerinti megoszlásához. Általában is ismert, hogy a fiatalok gyakoribb károkozók, a biztosítók a meghirdetett díjaikban nagyobb kockázatú csoportnak tartják a fiatalabb üzembentartókat. Erre vonatkozóan a saját állományi adataik alapján is tudnak következtetni, a kgfb-piacon alkalmazott dijszámítási modelljeik is ezt támasztják alá.

\section{I Általában is ismert, hogy a fiatalok gyakoribb károkozók.}

A személyi sérüléses károk arányait a 4. ábra mutatja. Azábrában csak azok az üzembentartók szerepelnek, akiknek ismert a KKTA-ban a születésiévük. Nem szerepelnek az adatok között az ún. ,nem természetes személyek”, a flottaszerződések üzembentartói és a hiányzó adatok sem. Az állományi adatok a 2011-2018 közötti időszak átlagos állományi megoszlását mutatják.

4. ábra: Az állomány és a személyi sérüléses kárt okozók életkor szerinti \%-os megoszlása és arányaik 2011-2018 között

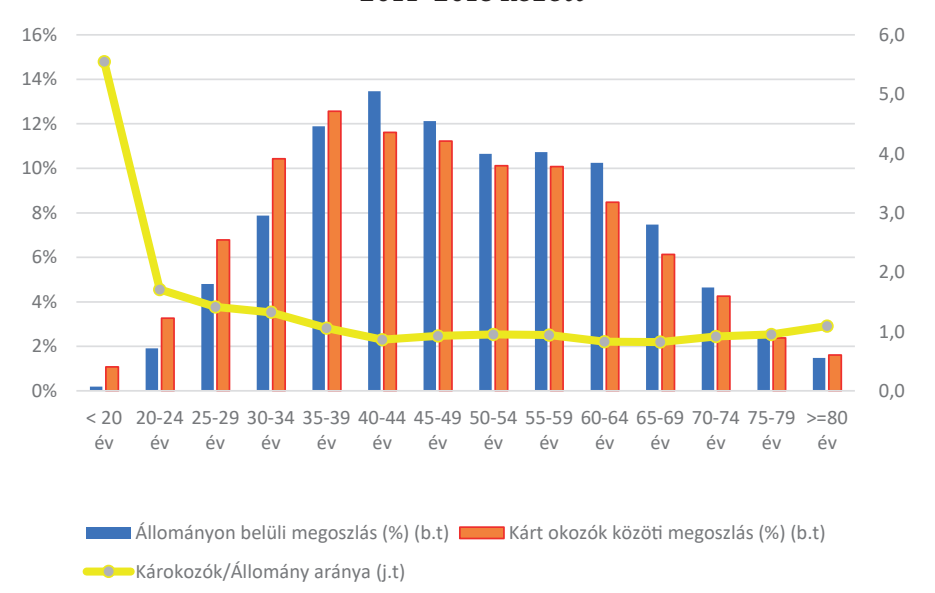

Forrás: $M N B$
A személyi sérüléses károk esetében is jól érzékelhető a fiatalok állományi megoszlásánál gyakoribb károkozása. Lényegében 35-39 éves kor között egyenlítődik ki a kétféle arány, ahogy a 4. ábra is mutatja, utána az idősebbek „kevesebb” kárt okoznak, majd 80 éves kor után ismét nagyobb a károk aránya. Igaz, itt már 2\%-nál kisebb az üzembentartók aránya is.

\section{Kgfb-járadékosok}

Elsősorban a magyarországi sérültek esetében jellemző a sérülésből adódó egészségkárosodás miatti rendszeres járadékszolgáltatás. Ennek fedezetére a biztosítók jogszabályban rögzített elvárásoknak megfelelő járadéktartalékot képeznek. Bár a „Sérült személy országa" sok esetben hiányzó adat, de a járadékosok esetében a káresemény országa elsősorban Magyarország. Külföldi sérültek nem szerepelnek a járadékosok között, de van külföldön történt balesetnek magyarországi járadékosa (3 eset). A tartalékok a célkitűzésben már említett 2020. 04. 15. hatálynapon érvényes állapotot mutatják. Jól látszik a képzett tartalékok nagy terjedelme, ami a sérülés súlyosságától, a sérült személy életkorától függően a különböző jogcímeken juttatott járadékokból adódóan a 9. táblázat alapján jelentős összeg is lehet.

9. áblázat: A KKTA rendszerben szereplő járadékosok főbb adatai

\begin{tabular}{|c|c|c|c|c|c|c|c|}
\hline $\begin{array}{c}\text { Kár bekö- } \\
\text { vetkezése (év) }\end{array}$ & $\begin{array}{c}\text { Jára- } \\
\text { dékosok } \\
\text { száma }\end{array}$ & $\begin{array}{c}\text { Járadéktartalék } \\
\text { összesen }\end{array}$ & $\begin{array}{l}\text { Átlagos jára- } \\
\text { déktartalék }\end{array}$ & $\begin{array}{c}\text { Minimális } \\
\text { járadéktartalék }\end{array}$ & $\begin{array}{c}\text { Maximális } \\
\text { járadéktartalék }\end{array}$ & $\begin{array}{c}\text { Összes } \\
\text { járadékkifizetés } \\
\begin{array}{c}\text { a lekérdezés } \\
\text { napjáig) }\end{array} \\
\end{array}$ & $\begin{array}{c}\text { Átlagos jára- } \\
\text { dékfelhasználás } \\
(\text { tartalék és eddigi } \\
\text { kifizetés együtt) }\end{array}$ \\
\hline 2011 & 51 & 1423753357 & 27916732 & 90000 & 410813534 & 218052676 & 32192275 \\
\hline 2012 & 39 & 1035728866 & 26557150 & 224990 & 255198460 & 120680415 & 29651520 \\
\hline 2013 & 70 & 1383844344 & 19769200 & 15000 & 187890809 & 148540200 & 21891208 \\
\hline 2014 & 66 & 1291577097 & 19569350 & 432067 & 311622810 & 120987809 & 21402499 \\
\hline 2015 & 46 & 1958652323 & 42579398 & 15000 & 630182764 & 62814806 & 43944938 \\
\hline 2016 & 39 & 624713654 & 16018299 & 997011 & 215836622 & 34424349 & 16900974 \\
\hline 2017 & 19 & 314273387 & 16540705 & 2191228 & 158856440 & 7101897 & 16914489 \\
\hline 2018 & 4 & 34801172 & 8700293 & 480506 & 27703257 & 971962 & 8943283 \\
\hline Összesen & 334 & 8067344200 & 24153725 & 15000 & 630182764 & 713574114 & 26290175 \\
\hline
\end{tabular}

Forrás: $M N B$

Megjegyzés: A járadékok megállapitása, az arra való jogalap tisztázása hosszabb folyamat, ezért szerepel még kevés eset a 2017-18-as károk között. A 2013 óta tartó csökkenő tendencia hátterében pedig a járadékok egyösszegü megváltása iránti szándék elterjedése állhat. 


\section{Fontosabb megállapítások}

A kötelező gépjármű-felelősségbiztosítás mint a nem-életbiztosítási piac kiemelt terméke a felügyelet számára is kiemelt fontosságú.

A személyi sérüléssel járó káresemények gyakorisága és

a keletkezett károk nagysága meghatározó része a termék

biztonságos múködéséhez szüikséges díjak meghatározásának.

A keletkezett károkon belül a személyi sérüléssel járó káresemények gyakorisága és a keletkezett károk nagysága meghatározó része a termék biztonságos müködéséhez szükséges díjak meghatározásának. Az elemzés fontosabb megállapításai a következők:

- A személyi sérüléses károk száma a 2012-es kedvező időszakhoz képest kismértékben ugyan, de folyamatosan emelkedett. (A 2018-as adat még nem teljes, néhány biztosítónál még nem szerepel az egész éves adat). A növekedés mértéke nagyjából követi a hazai jármüállomány változását.

- A KKTA rendszer adatai alapján vizsgált személyi sérüléses károk kárfelhasználása jelentősen eltér a hazai és a külföldön keletkezett károk között. Ez az összehasonlítás több mutató alapján is átlagosan másfélszeres kárfelhasználást jelent a külföldön keletkezett károk esetében (3. táblázat).

- A sérült személy szempontjából elsősorban a külföldön megsérült magyarországi károsultak átlagos kárráfordítása lett lényegesen magasabb a többi esetnél (5. táblázat).

- Az összehasonlítás azonban magába foglalja azokat a különbségeket, amelyek a hazai és külföldön történt káresemények rendezése során felmerülnek. Ahogy már utaltunk rá, a hazai károk nem tartalmazzák a biztosítók kötelezettségét a társadalombiztosítás felé (egészség- és nyugdíjbiztosítás), amit a MABISZ keretein belül egyösszegű megváltás formájában rendeznek. A külföldön történt károknál viszont megjelenik az ottani kórházi ellátás, ápolás, szállítás stb. költsége, de ha a károsult magyarországi lakos, akkor hazaszállítása után még sor kerülhet az itthoni további gyógykezelésére, amely szintén a MABISZ egyezség része. Ugyanakkor a külföldi személyi sérüléses károkhoz a rendelkezésre álló adatok alapján mindössze 4 esetben (3 magyarországi károsult, 1 hiányzó adat) fordul elő járadékszolgáltatás. Ezen járadékosok tartalékai (felelösségbiztosítási járadéktartalék) elsősorban a hazai károkra történő kárfelhasználást növelik a tartalék jogszabályban rögzített biztonságos mértéke miatt.

- A hazai károk mintegy 70\%-a még az adott évben ismertté válik, míg a nemzetközi károknál ez az arány 50-60\% körüli. A hazai károk kb. 98\%-a a káresemény bekövetkezését követő második év végére már bejelentésre kerül, a nemzetközi károk bejelentési üteme ennél lassúbb, és csak a káreseményt követő harmadik év végére érik el ezt a 98\% körüli arányt (6. táblázat).
- A nemzetközi károk leggyakoribb helyszínei, ahol az ország neve is ismert az adatszolgáltatásból: Nagy-Britannia, Németország, Ausztria, Olaszország és Románia. Ezekben az országokban történt a külföldi károk több mint fele, de szerepelnek távoli országok is (pl. Malajzia, Ausztrália, Szenegál, Namíbia) 1-1 káreseménnyel.

- A személyi sérüléses károk szempontjából is a fiatalok kockázatosabb csoportot alkotnak (4. ábra).

- A jogszabályban rögzített jármütípusok között a vontatók, a nagy személygépkocsik és az autóbuszok okoznak arányaiban több személyi sérüléses kárt. Az autóbuszok a benne utazókkal együtt mindenképp kockázatosabb járműkategóriát jelentenek (7. táblázat).

\section{IRODALOM JEGYZÉK}

[1.] 2009. evi LXII. torveny a kotelezô gépjarmü-felelösségbiztositasról [2. 20/2009 (X.9.) PM rendelet a kötelezö gépjármü-felelösségbiztositásnál alkalmazott gépjárműkategóriákró

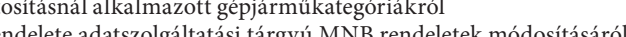
és hatályon kívül helyezéséről

[4.] (https://www.ksh.hu/docs/hun/xstadat/xstadat_evkozi/e_ods001.html) Letöltés dátuma 2021.04.08.

[5.] (https://www.ksh.hu/docs/hun/xstadat/xstadat_eves/__qsfo01.html) Letöltés dátuma 2021.04.08. 